\title{
Economic Sustainability of Highly Vulnerable Countries under Climate Change
}

\author{
Marcelo Mazzolli ${ }^{1}$ \\ ${ }^{1}$ Universidade do Planalto Catarinense (UNIPLAC), Lages, Brazil \\ Correspondence: Marcelo Mazzolli, Universidade do Planalto Catarinense (UNIPLAC), Av. Castelo branco, 170, \\ Lages, 88509-900, Brazil; R. Liberato Carioni 247, Lagoa da Conceição- Village III, 88062-205, Florianópolis, \\ Brazil. Tel: 55-49-3251-1157. E-mail: puma@uniplac.net
}

Received: March 15, 2012 Accepted: June 19, 2012 Online Published: June 28, 2012

doi:10.5539/jsd.v5n7p166 URL: http://dx.doi.org/10.5539/jsd.v5n7p166

The research is financed by FAPESC and project Aquifero Guarani/Serra Geral Network

\begin{abstract}
It is not known whether impacts of climate change may grow so intense as to threaten permanently the economic sustainability of countries. In this article, the mid-term impact of climate change was modeled for countries ranked amongst the most vulnerable to climate change. The Gross National Income (GNI) growth rates of three countries highly vulnerable to climate change (Pakistan, Somalia and Burkina Faso) were compared with expected economic losses from disasters, using a dataset that spanned from 1980 to 2010. It was found, in average, that GNI have doubled each decade, while economic losses to disaster have doubled every three decades. The results suggest that the impact is likely to be smaller in the future than it is now, as long as growth rates of both GNI and climate-related losses are maintained. Given the current scenario, localized regions and economies are the ones that seem to be most likely to be affected by climate change.
\end{abstract}

Keywords: economy, geopolitics, natural disasters, thresholds

\section{Introduction}

\subsection{Climate is Changing}

The current level or stock of greenhouse gases in the atmosphere is equivalent to around 430 parts per million (ppm) $\mathrm{CO}_{2}$ compared with only 280ppm prior to industrial revolution (Stern, 2007) and during the period of 420 thousand years BP (Petit et al., 1999). Evidences of climate change are also given by the increasing frequency and intensity of disasters, sea level and temperature rise, reduction of ice coverage, acidification of the ocean (with bleaching of coral reefs), and changes in Atlantic Ocean overturning. Climate-related disasters are particularly compromising sustainability of people from countries that are economically disadvantaged and environmentally vulnerable.

\subsection{Unsustainable versus Unberable Livehood Conditions}

Sustainability is measured using several well known indexes such as volume of carbon emissions, Human Developmente Index (HDI), adjusted net savings, ecological footprints, GNI, and so on. When compared and/or combined, they are very useful in the understanding of patterns and disparities that should be addressed worldwide: a couple of examples are the positive relationship of high HDI countries with carbon emission, and higher costs (in \% GNI) of climate-related disasters in low HDI countries (Human Development Report 2011, UNDP). Based on those indexes, however, both high and low HDI countries are labeled as unsustainable, irrespective of differences in resilience. Unbearable is the alternative definition of unsustainable that may be employed to describe the situation of those countries holding economies that are already chronically unsustainable (those that have most of population living under the povety line), and that are now having to deal with an increase of climatic disasters. We are thus concerned with extreme and irreversible livelihood conditions caused by climatic disasters prior to sea-rise flooding. The action to reduce disasters of climatic nature is called adaptation. 


\subsection{The Cost of Adaptation}

Sub-Saharan Africa is the region that has contributed the least to the global accumulation of greenhouse gas emissions, but is the most vulnerable to the impact of climate change. It is estimated that the total cost of Africa's adaptation to climate change will be at least $\$ 18$ billion a year by 2030. The funding that is currently delivered is far from fulfilling these needs (Nakhooda et al., 2011). Adaptation funds do not replace the need for emergency funds, which have been insufficient to alleviate disasters.

Emergency and adaptation funds have been insuficient to supply current needs, raising the concern that most of the burden of disasters may have to be dealt by countries affected. In 2011 adaptation funds mobilized $\$ 957 \mathrm{~m}$ worldwide, while disasters in Somalia alone during this year consumed $\$ 820 \mathrm{~m}$ of emergency funds. Pakistan registered $\$ 9.5 \mathrm{~b}$ in losses, received $\$ 759 \mathrm{~m}$ of emergency funds, and a little over $1 \mathrm{~m}$ of adaptation fund transferred in 2010. There is not short-term perspective to increase funds to developing countries. Draft decision of the report of the adaptation funding at Durban (Conference of the Parties on Climate Change - COP 17) approved only $\$ 70.2 \mathrm{~m}$. Top 5 underfunded appeals are public (as from Jan 2012): Nicarágua 28\%, West Africa $38 \%$, El Salvador 39\%, Namibia 44\%, Pakistan 46\% (OCHA, 2012). In the Horn of Africa, drought associated with poverty and social chaos produce famine - 13 million people are or have been on the verge of starvation, and hundreds of thousands have had to migrate to refugee camps for assistance, a situation that have been considered 'the most severe humanitarian emergency in the world' according to UNICEF.

The volume of underfunded appeals raised the concern for us that there are not enough humanitarian funds to cover all the disasters in the intensity in which they come, and the impression is that low income countries are not able to cope by themselves, currently or in the future. To investigate that, we modeled future losses and revenues of three of the most vulnerable countries that had a dataset complete enough to fit the model.

\section{Research Methods}

To explore how predicted increase in disaster may affect the economy of vulnerable countries, we compared GNI growth rates with expected economic losses from disasters, for three countries.

Public databases are quite incomplete in terms of economic losses to disasters, so this had to be modeled. To model it, we calculated the Average Loss in Percentage of the GNI (abbreviated as ALPG) for four developing countries that had major losses in 2010, China, Mexico, India and Pakistan. The year 2010 behaved as an average year in terms of economic losses to climate-related disasters since 2006 (Munick Re's NatCat, 2012). We did not find figures for the other countries analyzed here during this given year. We then used this calculated ALPG to simulate future losses for Pakistan, Somalia and Burkina Faso for coming years.

We did not find reliable information on the historical rate of increase in economic losses prior to 2004, so we assumed that the rate of increase of ALPG doubled at periods of 30 years $(2 \times 30 y)$ similar to the historical rate of increase in number of number of events since 1980 (Munick Re's NatCat, 2012). The relative losses were modeled from 2020 to 2050 .

\section{Results}

Our results suggest that the GNIs of low-income developing countries (Pakistan, Burkina Faso, and Somalia) are expected to grow at a higher rate than that of climate-related disasters. Their GNI are expected to double each decade, whereas disasters double in intensity at every three decades (data from 1980-2010) (Figure 1).

Somalia is the smaller economy, it starts 2020 with a loss of 76 million USD, reaching forecasted losses of 675 million USD by 2050. Burkina Faso has an intermediate economy, it starts with 358 million USD and ends up with almost 7 billion USD losses by 2050. Pakistan is the wealthiest of the economies, it starts with amazing 7.6 billion USD and ends up with almost 147 billion USD in losses. 

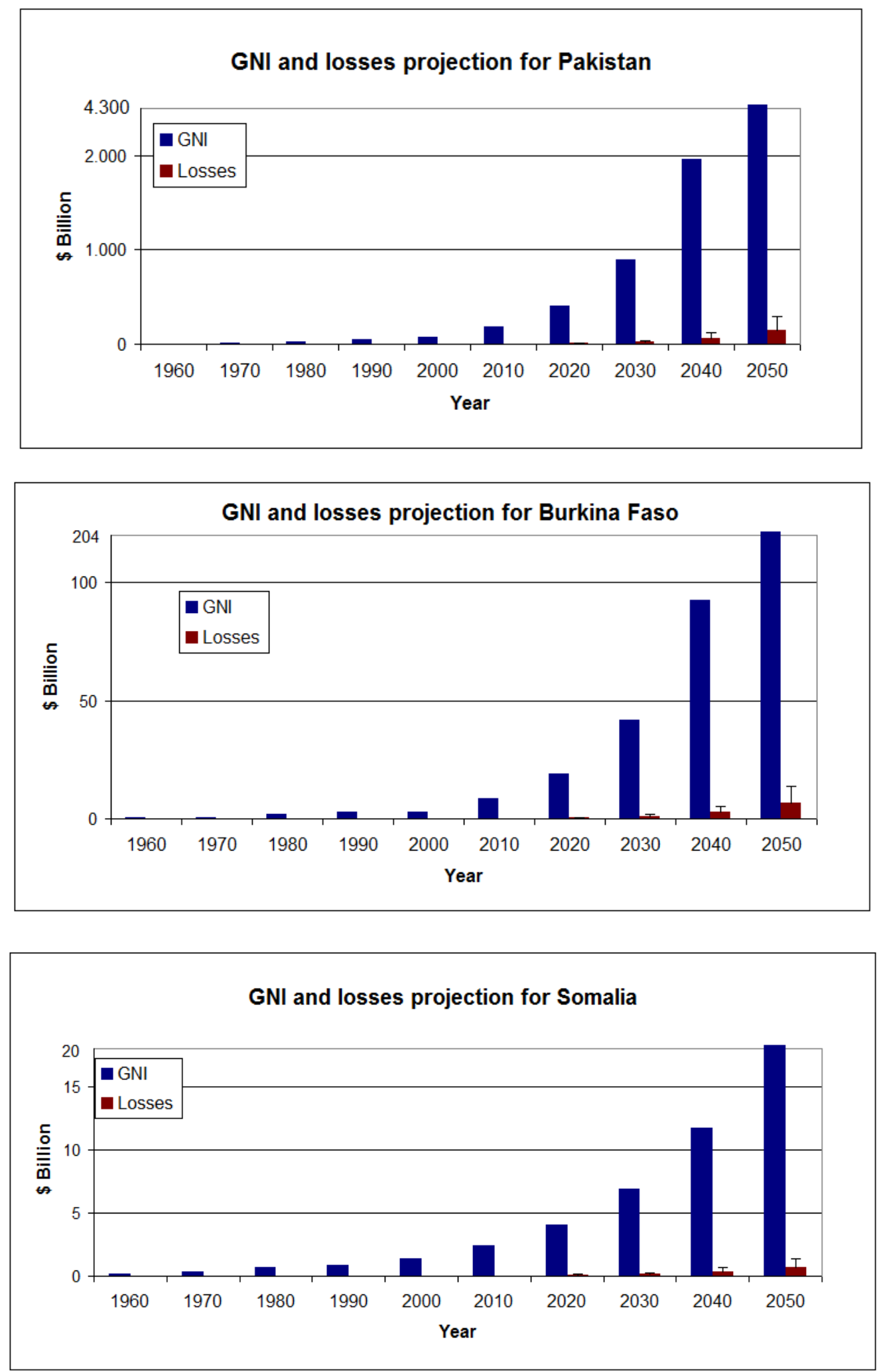

Figure 1. GNI and losses projection for three countries vulnerable to climate change

Projection of GNI for Pakistan, Burkina Faso, and Somalia based on historical data (data from World Bank). Projection of losses from 2020 to 2050, based on the average losses of four countries holding the highest losses in the year 2010, and doubling at every thirty years (dataset from Munick Re since 1980). 
Data reveals how relative are losses when weighed against GNI. China had a higher loss than Pakistan in numerical value, but it represented only 0.2 of its GNI, while Pakistan losses represented 5.19\% of its GNI (Table 1).

Table 1. Data used to model the GNI - loss-to-disaster rate

\begin{tabular}{|c|c|c|c|c|c|}
\hline Country & $\begin{array}{c}\text { Losses } 2010 \\
\qquad \mathrm{~b}\end{array}$ & $\begin{array}{l}\text { GNI } \\
\$ \$ b\end{array}$ & Losses $2010 \%$ GNI & $\begin{array}{c}\text { GNI growth } \\
\text { rate }(\mathrm{X}) / \text { decade }\end{array}$ & $\begin{array}{c}\text { GNI growth rate } \\
\text { (SD)/ decade }\end{array}$ \\
\hline Pakistan & 9.5 & 183 & 5.19 & 2.2 & 0.6 \\
\hline Somalia & - & - & - & 1.7 & 0.4 \\
\hline Burkina & - & - & - & 2.2 & 1.2 \\
\hline \multicolumn{6}{|l|}{ Faso } \\
\hline China & 11.9 & 5957 & 0,20 & - & - \\
\hline Mexico & 3.9 & 1020 & 0,38 & - & - \\
\hline India & 0.6 & 1712 & 0,04 & - & - \\
\hline $\begin{array}{l}\text { Average } \\
(\mathrm{X})\end{array}$ & 6.5 & 2218.0 & 1.5 & 2.0 & 0.7 \\
\hline $\mathrm{SD}$ & 5.2 & 2569.9 & 2.5 & 0.3 & 0.4 \\
\hline
\end{tabular}

Average loss in 2010 for countries with available data were used to model future losses in vulnerable countries (Pakistan, Somalia, and Burkina Faso). GNI data from World Bank, loss data from NatCat (Munick Re).

\section{Discussion}

Results suggest that the average rate of disasters' impact on GNI has been lower so far than the rate of increase of GNI, even for the vulnerable countries modeled here. That means that the impact is likely to be smaller in the future than it is now, as long as growth rates of both GNI and climate-related losses are maintained. Corroboratively, Horwich (2000) and Clower (2005) argue that even smaller nations appear to possess economic resilience to disaster events.

Keeping up with the same rate of GNI increase will require adapting production to reduce the reliance on products that are vulnerable to climate change, something utterly difficult in low income rural areas, which are ultimately responsible for a large share of the GNI in developing countries. Furthermore, districts may be permanently affected even when the economy of the country is not. Poverty is currently unbearable in some low-income countries, where $80 \%$ of the population may be under the poverty line - climate change may still increase inequalities under these circumstances.

Regarding the basic assumptions of our model, we refrained from applying 'real' values of the average economic losses to different economies, assuming that countries are more likely to loose in proportion of their wealth. For example, the $9.5 \$$ b loss in Pakistan represented 5\% of its GNI of 183 b, but would represent $100 \%$ of Burkina Faso's GNI, in a single disaster, an alarming proportion from all viewpoints. As national income rises, disaster costs tend to rise, but relative costs as well as the number of lives lost decrease (Dacy \& Kunreuther, 1969; Freeman et al., 2003).

Having said that, this does not diminish the growing concern to livehoods raised by the perspective of increasing disasters. Over 10 million people have been affected by drough and floods in the Horn of Africa and Pakistan alone, respectively, during the 2010 and 2011 period. Given the current scenario, localized regions and economies are the ones that seem to be most likely to be affected by climate change.

\section{References}

Clower, T. (2005). Economic applications in disaster research, mitigation, and planning. In McEntire, D. (Ed.), Disciplines, Disasters and Emergency Management: The Convergence and Divergence of Concepts, Issues and Trends in the Research Literature. Washington, DC: Federal Emergency Management Agency.

Dacy, D., \& Kunreuther, H. (1969). The Economics of Natural Disasters: Implications for Federal Policy. New York: The Free Press. 
Freeman, P., Keen, M., \& Mani, M. (2003). Dealing with Increased Risk of Natural Disasters: Challenges and Options. IMF Working Paper No. 03/197. Washington, DC: International Monetary Fund.

Horwich, G. (2000). Economic lessons of the Kobe earthquake. Economic Development and Cultural Change, 48(3), 521-522.

Munick Re's NatCat. (2012). Natcatservice. Retrieved January, 2012, from http://www.munichre.com/en/reinsurance/business/non-life/georisks/natcatservice/default.aspx

Nakhooda, S., Caravani, A., Bird, N., \& Schalatek, L. (2011). Climate finance in Sub-Saharan Africa. Climate Finance Policy Brief. Heinrich Boell Foundation and Overseas Development Institute (ODI), Washington D.C. and London.

OCHA. (2012). Financial Tracking System. UN Office for the Coordination of Humanitarian Affairs (OCHA). Retrieved January, 2012, from http://fts.unocha.org

Petit, J. R., Jouzel, J., Raynaud, D., Barkov, N. I., Barnola, J. M., Basile, I., ... Stievenard, M. (1999). Climate and atmospheric history of the past 420,000 years from the Vostok ice core, Antarctica. Nature, 399, 429-436.

Stern, N. (2007). The economics of climate change. Stern Review. Cambridge, UK: Cambridge University Press.

UNDP. (2011). Human Development Report 2011: Sustainability and equity: a better future for all. United Nations Development Programme. Palgrave Macmillan, NY. 